\title{
Xanthan Pyruvilation Is Essential for the Virulence of Xanthomonas campestris pv. campestris
}

\author{
María Isabel Bianco, ${ }^{1}$ Laila Toum, ${ }^{1}$ Pablo Marcelo Yaryura, ${ }^{2}$ Natalia Mielnichuk, ${ }^{1}$ \\ Gustavo Eduardo Gudesblat, ${ }^{1,3}$ Roxana Roeschlin, ${ }^{4}$ María Rosa Marano, ${ }^{4}$ Luis lelpi, ${ }^{5}$ and \\ Adrián A. Vojnov ${ }^{1}$ \\ ${ }^{1}$ Instituto de Ciencia y Tecnología Dr. César Milstein, Fundación Pablo Cassará, Consejo Nacional de Investigaciones \\ Científicas y Técnicas (CONICET), Saladillo 2468 (C1440FFX), Ciudad de Buenos Aires, Argentina; ${ }^{2}$ Centro de Investigaciones \\ y Transferencia (CIT Villa María), CONICET-Instituto de Ciencias Básicas y Aplicadas, Universidad Nacional de Villa María. Av. \\ Arturo Jauretche 1555, (5900), Villa María, Córdoba, Argentina; ${ }^{3}$ nstituto de Biodiversidad y Biología Experimental y Aplicada \\ (IBBEA), Departamento de Biodiversidad y Biología Experimental (DBBE), CONICET, Facultad de Ciencias Exactas y \\ Naturales, Universidad de Buenos Aires, Intendente Güiraldes 2160, Buenos Aires (C1428EGA), Argentina; ${ }^{4}$ Instituto de \\ Biología Molecular y Celular de Rosario (IBR)-CONICET, Área Virología, Facultad de Ciencias Bioquímicas y Farmacéuticas, \\ Universidad Nacional de Rosario (UNR), Ocampo y Esmeralda s/n, (S2000FHN) Rosario, Argentina; and ${ }^{5}$ Laboratorio de \\ Genética Bacteriana, Fundación Instituto Leloir, Instituto de Investigaciones Bioquímicas de Buenos Aires (IIBBA)-CONICET, \\ Patricias Argentinas 435 (C1405BWE), Ciudad de Buenos Aires, Argentina
}

Accepted 26 July 2016.

\begin{abstract}
Xanthan, the main exopolysaccharide (EPS) synthesized by Xanthomonas spp., contributes to bacterial stress tolerance and enhances attachment to plant surfaces by helping in biofilm formation. Therefore, xanthan is essential for successful colonization and growth in planta and has also been proposed to be involved in the promotion of pathogenesis by calcium ion chelation and, hence, in the suppression of the plant defense responses in which this cation acts as a signal. The aim of this work was to study the relationship between xanthan structure and its role as a virulence factor. We analyzed four Xanthomonas campestris pv. campestris mutants that synthesize structural variants of xanthan. We found that the lack of acetyl groups that decorate the internal mannose residues, ketal-pyruvate groups, and external mannose residues affects bacterial adhesion and biofilm architecture. In addition, the mutants that synthesized EPS without pyruvilation or without the external mannose residues did not develop disease symptoms in Arabidopsis thaliana. We also observed that the presence of the external mannose residues and, hence, pyruvilation is required for xanthan to suppress callose deposition as well as to interfere with stomatal defense. In conclusion, pyruvilation of xanthan seems to be essential for Xanthomonas campestris pv. campestris virulence.
\end{abstract}

The genus Xanthomonas comprises several phytopathogenic species that cause a variety of worldwide economically important diseases in monocotyledonous and dicotyledonous crops. Xanthomonas spp. produce a range of virulence factors, such as adhesins, extracellular degradative enzymes, lipopolysaccharides,

M. I. Bianco and L. Toum contributed equally to this work.

Corresponding author: A. A. Vojnov; Telephone +54.11.4686.3687; E-mail: avojnov@fundacioncassara.org.ar.

*The $\boldsymbol{e}$-Xtra logo stands for "electronic extra" and indicates that three supplementary figures are published online.

(c) 2016 The American Phytopathological Society and exopolysaccharides (EPSs) (Büttner and Bonas 2010). Xanthan, the main EPS synthesized by most species of the genus, is essential for bacterial virulence and disease progression (Aslam et al. 2008; Dow and Daniels 1994; Yun et al. 2006).

Xanthan is a branched acidic hetero-polysaccharide composed of penta-saccharide repeating units. This macromolecule consists of a cellulose backbone with a trisaccharide side chain on every other glucose at C-3, containing a glucuronic acid (GlcA) residue linked to a mannose that connects to the backbone $\left(\operatorname{Man}_{\text {int }}\right)$ and a second terminal mannose $\left(\operatorname{Man}_{\text {ext }}\right)$ (Jansson et al. 1975) (Supplementary Fig. S1A). The mannose residues of the repetitive units of xanthan can be substituted by nonglycosidic groups as acetyl and ketal-pyruvate (ketal-Pyr) groups. Depending on the Xanthomonas strain and environmental conditions, approximately $90 \%$ of the $\mathrm{Man}_{\text {int }}$ residues can be acetylated and 30 to $50 \%$ of the $\mathrm{Man}_{\mathrm{ext}}$ residues can carry ketal-Pyr substituents at specific sites (Cadmus et al. 1976; Stankowski et al. 1993). In addition, the $\mathrm{Man}_{\mathrm{ext}}$ residues can also be substituted by acetyl groups (Cadmus et al. 1976; Stankowski et al. 1993).

The steps involved in xanthan biosynthesis have been previously described (Ielpi et al. 1993). The production of xanthan is directed under the control of several genetic loci, including the gum gene cluster, which consists of 12 genes (gum $\mathrm{B}$ to gum $\mathrm{M}$ ). The gum $\mathrm{D}$, gum $\mathrm{M}, g u m \mathrm{H}, g u m \mathrm{~K}$, and gum I genes encode a set of glycosyltransferases that are responsible for the ordered synthesis of a lipid-linked penta-saccharide (Betlach et al. 1987; Katzen et al. 1998), while gumB, gumC, and gum $\mathrm{E}$ encode proteins involved in xanthan polymerization and export processes (Galvan et al. 2013). Finally, gumF, gum G, and gumL codify for two acetyl- and one pyruvyl-transferase, respectively (Ielpi et al. 1981; Katzen et al. 1998; Vojnov et al. 1998, 2001, 2002).

The molecular composition of xanthan, particularly its substitution with nonglycosidic groups, affects the orderdisorder transition of this EPS and, hence, its structure. Acetyl substituents promote a more ordered conformation by interaction with the cellulose backbone through hydrogen or 
hydrophobic bonding (Dentini et al. 1984; Shatwell et al. 1990). The opposite is true for ketal-Pyr groups, which cause a destabilizing effect attributed to an increase in electrostatic charge repulsion between these substituents and GlcA residues, thus leading to a more disordered conformation (Shatwell et al. 1990). It has been proposed that the negative charges provided by both GlcA residues and ketal-Pyr groups allow xanthan to chelate cations (Tako and Nakamura 1987). However, a further work proposed that ketal-Pyr groups are the main site for cation binding because of their localization in the terminal end of the side chains of xanthan (Bergmann et al. 2008).

Due to its highly hydrated and poly-anionic character, xanthan protects bacteria from adverse environmental conditions and, in vascular plant pathogens such as Xanthomonas campestris pv. campestris, xanthan blocks xylem tubes, thus affecting the flow of water and nutrients, which can cause wilting of the host (Chan and Goodwin 1999; Denny 1995). Xanthan also plays a significant role in biofilm formation during plant colonization by Xanthomonas spp. (Dow et al. 2003; Rigano et al. 2007a; Torres et al. 2007). The biofilm extracellular matrix is composed of a variety of hydrated extracellular polymeric substances that build an essential scaffold for biofilm development. Particularly, EPSs bind considerable amounts of water molecules, maintaining a highly hydrated microenvironment around the biofilm and promoting host colonization (Flemming and Wingender 2010). Thus, xanthan contributes to bacterial epiphytic survival before colonization of the host plant, since biofilms play a crucial role, both in the epiphytic stage of the bacterial life cycle and during plant colonization (Rigano et al. 2007a; Stoodley et al. 2002; Vojnov and Marano 2015).

Because bacteria cannot directly penetrate the leaf epidermis, endophytic colonization occurs through natural openings, such as hydathodes and stomata, or through accidental wounds (Sawinski et al. 2013). Stomatal pores, delimited by two guard cells, regulate plant gas exchange and transpiration through changes in their aperture in response to external cues like photosynthetic effective illumination, $\mathrm{CO}_{2}$ levels, and water availability and internal signals like the stress hormone abscisic acid (ABA) (Sirichandra et al. 2009). Since stomata offer pathogens a way for endophytic colonization, they have also evolved mechanisms to close in response to microbialassociated molecular patterns (MAMPs) including bacterial flagellin, elongation factor $\mathrm{Tu}$, and lipopolysaccharide, thus preventing microbial invasion. Particularly, it has been demonstrated that stomatal closure elicited by the flagellin-derived 22-amino acid peptide (flg22) limits bacterial colonization and disease progression (Melotto et al. 2006; Zeng and He 2010; Zipfel et al. 2004). Therefore, this mechanism represents an important layer of active immunity at the preinvasive level (Sawinski et al. 2013). In response to different stimuli, stomatal closure is brought about by loss of turgor of guard cells, which is caused by the extrusion of solutes through different ion channels. The signaling cascade that leads to stomatal closure includes an increase in cytosolic $\mathrm{Ca}^{2+}$ concentration (Joshi-Saha et al. 2011; Kim et al. 2010; Kollist et al. 2014). Chelation of this ion with EGTA (ethylene glycol-bis[ $\beta$-aminoethyl ether]-N,N, ${ }^{\prime}, N^{\prime}$-tetraacetic acid) strongly inhibits ABA-induced stomatal closure (Webb et al. 1996). Previous studies have demonstrated that xanthan enhances $X$. campestris pv. campestris virulence by inhibiting $\mathrm{Ca}^{2+}$ signaling during the host immune response through chelation of this ion (Aslam et al. 2008; Enrique et al. 2011; Yun et al. 2006). It has also been shown that xanthan lacking both ketal-Pyr and acetyl groups has a 50\% lower ability to sequester $\mathrm{Ca}^{2+}$ and to suppress flg22-induced $\mathrm{Ca}^{2+}$ influx than the wild-type (WT) polymer (Aslam et al.
2008). However, the possible effect of xanthan on stomatal immunity has not yet been studied.

The aim of this work was to analyze how changes in xanthan composition and, hence, in its structure impact on its role in $X$. campestris pv. campestris pathogenicity. For this purpose, we analyzed how alterations in the xanthan molecule affect bacterial adhesion, biofilm formation, disease symptoms, and bacterial growth in planta and the host responses to $X$. campestris pv. campestris infection as callose deposition and stomatal closure.

\section{RESULTS}

We used a set of $X$. campestris pv. campestris mutants affected in different steps of xanthan biosynthesis that synthesized different structural variants of xanthan (SV-Xan) (Table 1). As controls, we used a WT strain $(\mathrm{XcFC} 2)$ and a xanthan-defective mutant that lacks the gum operon (Xc1231) and, thus, produces no xanthan at all (Capage et al. 1987). All X. campestris pv. campestris strains showed similar duplication times in culture medium and reached stationary growth phase at $72 \mathrm{~h}$ (data not shown).

\section{Lack of acetylation of $\operatorname{Man}_{\text {int }}$, pyruvilation of $\operatorname{Man}_{\text {ext }}$, or absence of $\mathrm{Man}_{\text {ext }}$ affect bacterial adhesion and biofilm architecture.}

$X$. campestris pv. campestris biofilm formation is important for bacterial pathogenicity (Rigano et al. 2007a). Therefore, in a preliminary assay, we analyzed bacterial adhesion of the different $X$. campestris pv. campestris mutants to polystyrene microtiter plates by crystal violet staining at 24,48 , and $72 \mathrm{~h}$ postincubation (data not shown). All $X$. campestris pv. campestris mutants exhibited a diminished ability to adhere to the abiotic surface, showing the largest differences in attached bacteria at $72 \mathrm{~h}$ postincubation (Fig. 1A). Consequently, we used this time point in subsequent experiments. As expected, the xanthan-defective strain Xc1231 exhibited the strongest reduction in adhesion. Of the other mutants, XcI showed the lowest bacterial adhesion with $55 \%$ reduction relative to $\mathrm{XcFC} 2$, while $\mathrm{XcF}$ and $\mathrm{XcL}$ showed a reduction in adhesion of 35 and $25 \%$, respectively (Fig. 1A). On the other hand, although the absence of acetyl substituents of Man ext $_{\text {affects }}$

Table 1. Characteristics of structural variants of xanthan (SV-Xan) produced by the different Xanthomonas campestris pv. campestris mutant strains

\begin{tabular}{|c|c|c|}
\hline \multirow[b]{2}{*}{ Strain } & \multicolumn{2}{|c|}{ Structural variant of xanthan } \\
\hline & Name & Characteristics $^{\mathbf{a}}$ \\
\hline $\mathrm{XcFC} 2^{\mathrm{b}}$ & XanWT & $\begin{array}{l}\text { Penta-saccharidic repetitive units } \\
\text { Man }_{\text {int }} \text { acetylated } \\
\text { Man }_{\text {ext }} \text { acetylated/pyruvilated }\end{array}$ \\
\hline $\mathrm{Xc} 1231^{\mathrm{c}}$ & - & Non xanthan production \\
\hline $\mathrm{XcF}^{\mathrm{b}}$ & SV-XanF & $\begin{array}{l}\text { Penta-saccharidic repetitive units } \\
\text { Man }_{\text {int }} \text { without acetyl groups. } \\
\text { Man }_{\text {ext }} \text { acetylated/pyruvilated }\end{array}$ \\
\hline $\mathrm{XcG}^{\mathrm{b}}$ & SV-XanG & $\begin{array}{l}\text { Penta-saccharidic repetitive units } \\
\text { Man }_{\text {int }} \text { acetylated } \\
\text { Man }_{\text {ext }} \text { pyruvilated }\end{array}$ \\
\hline$X \mathrm{CL}^{\mathrm{b}}$ & SV-XanL & $\begin{array}{l}\text { Penta-saccharidic repetitive units } \\
\text { Man }_{\text {int }} \text { acetylated } \\
\text { Man }_{\text {ext }} \text { acetylated }\end{array}$ \\
\hline $\mathrm{XcI}^{\mathrm{b}}$ & SV-XanI & $\begin{array}{l}\text { Tetra-saccharidic repetitive units } \\
\text { Man }_{\text {int }} \text { acetylated } \\
\text { Without } \text { Man }_{\text {ext }}\end{array}$ \\
\hline $\begin{array}{l}\text { a } \text { Man }_{\text {int }} \\
\text { termina } \\
\text { b Katzen } \\
\text { c Capage }\end{array}$ & that con & backbone; $\operatorname{Man}_{\text {ext }}=$ a second \\
\hline
\end{tabular}


A

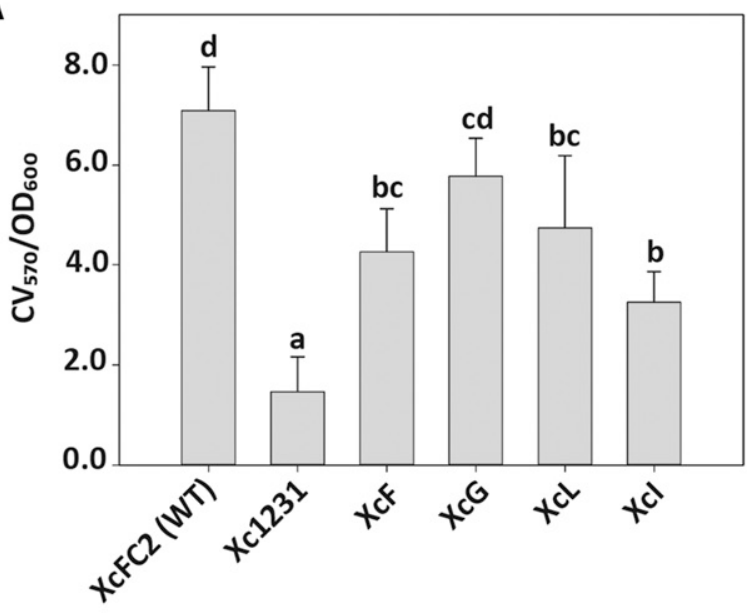

B

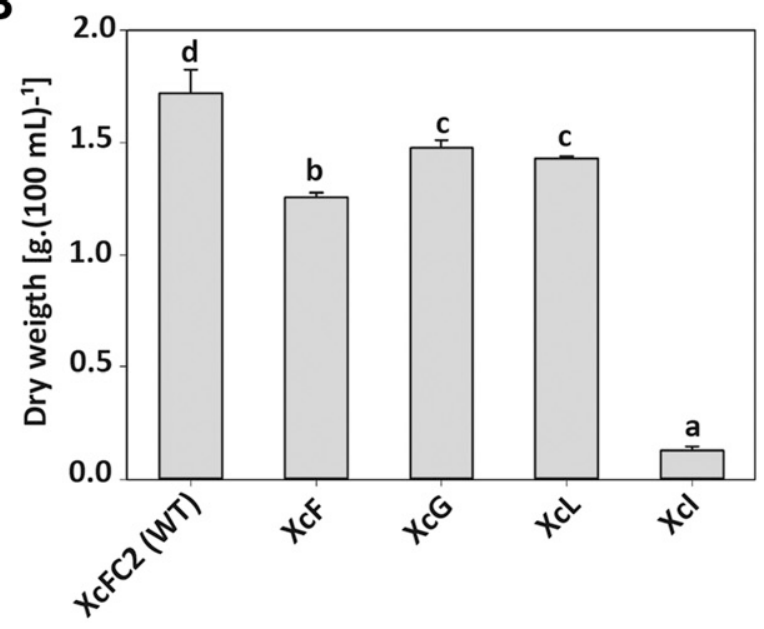

C

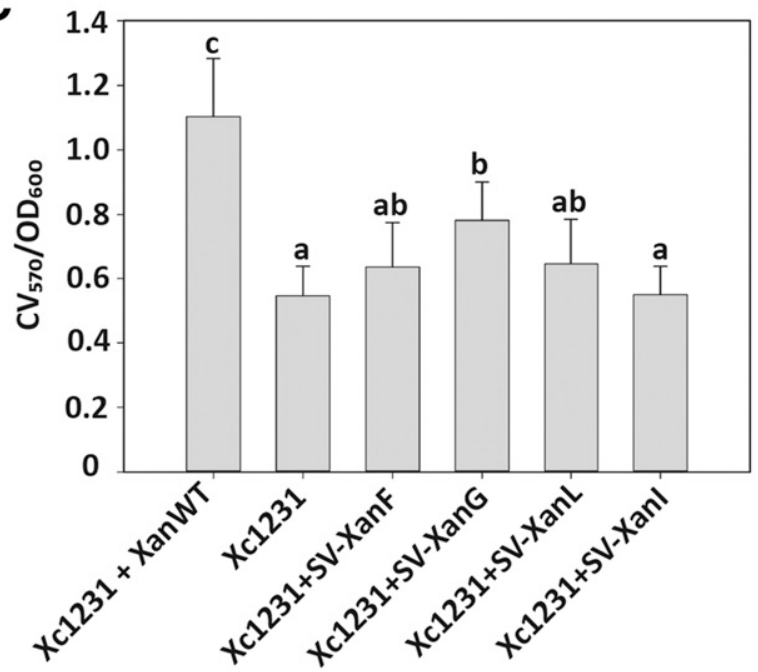

Fig. 1. Adhesion of Xanthomonas campestris pv. campestris strains to an inert abiotic surface. A, $X$. campestris pv. campestris mutants grown in $\mathrm{Y}$ minimal medium (YMM). B, Exopolysaccharide (EPS) production of $X$. campestris $\mathrm{pv}$. campestris strains grown in peptone-yeast extract-malt extract medium for 5 days. The amount of EPS was determined as dry weight after isopropanol precipitation. Each bar represents the mean and standard deviation (SD) from three independent trials, each with three replicates. C, Xc1231 grown in YMM supplied with the different different structural variants of xanthan (SV-Xan) $\left(200 \mu \mathrm{g} \mathrm{ml}^{-1}\right)$. In both cases, the $y$ axis shows the ratio between crystal violet absorbance $(570 \mathrm{~nm})$ and bacterial growth $(600 \mathrm{~nm})\left(\mathrm{CV}_{570} / \mathrm{OD}_{600}\right)$. Each bar represents the mean and SD from six independent trials, each with ten replicates. For A, B, and C, different letters indicate significant differences (one-way analysis of variance, $P<0.05$ ) based on the Tukey test. adhesion, XcG was not significantly affected in this trait relative to XcFC2 (Fig. 1A).

Next, we measured the amount of EPS synthesized by each strain, to investigate whether it, per se, affected the adhesion of the $X$. campestris pv. campestris mutant strains. We noticed that all mutants produced significantly less EPS than the WT strain, ranging between 14 to $92 \%$ relative to $\mathrm{XcFC} 2$ (Fig. 1B). Interestingly, XcG and XcL produced similar amounts of EPS but exhibited significantly different adhesion values. These results suggest that changes in xanthan structure could also affect bacterial adhesion. To test this hypothesis, we cultured the Xc1231 strain in a medium supplemented with comparable amounts of the different SV-Xan. Xanthan produced by the WT strain (XanWT) improved $90 \%$ the adhesion of Xc1231 relative to the control without added EPS (Fig. 1C). SV-XanG also significantly restored adhesion of Xc1231, although not to the level of XanWT. By contrast, SV-XanF and SV-XanL increased Xc1231 adhesion by only 16 and $18 \%$, respectively, while SVXanI showed no effect (Fig. 1C). These results indicate that the lack of acetylation in $\mathrm{Man}_{\text {int }}(\mathrm{XcF}$ mutant), pyruvilation in $\operatorname{Man}_{\text {ext }}$ (XcL mutant), and the absence of $\operatorname{Man}_{\text {ext }}$ (XcI mutant) impair bacterial adhesion.

In further experiments, we used inverted confocal laser scanning microscopy (CLSM) to analyze the biofilm structure developed by the $X$. campestris pv. campestris mutants at 24, 48, and 72 h (Supplementary Fig. S2). After 72 h, the WT strain $\mathrm{XcFC} 2$ developed a mature biofilm with a characteristic architecture, while the xanthan-deficient strain Xc1231 failed to form microcolonies and complex structures, as expected from adhesion experiments (Fig. 2). XcG exhibited a biofilm architecture similar to that produced by $\mathrm{XcFC} 2$, whereas the other three $X$. campestris pv. campestris mutants developed biofilm structures different from that formed by the WT strain (Fig. 2). $\mathrm{XcF}$ formed a biofilm thinner than that produced by the $\mathrm{XcFC}$. $\mathrm{XcL}$ formed a biofilm with a similar thickness to that formed by $\mathrm{XcFC} 2$ but with more bacterial aggregates, while XcI developed a thinner and more compact biofilm than XcFC2 (Fig. 2). These distinct biofilm patterns were reproduced in two independent experiments.

To gain further insights into the biological relevance of the modifications in the biofilms produced by the $X$. campestris pv. campestris mutants, we conducted a quantitative analysis of their structures using confocal imaging of biofilms, followed by image analysis with COMSTAT software (Heydorn et al. 2000). We evaluated the average thickness, biomass, and roughness coefficient of biofilms as well as bacterial average diffusion distance (Table 2). The roughness coefficient estimates the heterogeneity of the biofilm, considering how its thickness varies; hence, the lower the value, the more compact, flat, and uniform the biofilm (Murga et al. 1995). The diffusion distance for a pixel containing biomass is the shortest distance from that pixel to a pixel not containing biomass. The average diffusion distance is the average of diffusion distances among all biomass pixels, whereas the maximum diffusion distance is the maximum of diffusion distances among all biomass pixels (Heydorn et al. 2000). Thus, this parameter quantifies the distance over which nutrients and other substrate components have to diffuse from the void space to bacteria within microcolonies. High diffusion distance values indicate large aggregates of biomass and cell clusters and, hence, a more confluent and compact biofilm.

The average thickness and biomass values of biofilms produced by the different $X$. campestris pv. campestris mutants showed no major changes as compared with those observed for $\mathrm{XcFC} 2$ (Table 2). However, $\mathrm{XcF}$ and $\mathrm{XcI}$ mutants showed higher diffusion distance values than $\mathrm{XcFC} 2, \mathrm{XcL}$, and $\mathrm{XcG}$ (Table 2). Moreover, the roughness coefficients of the biofilms 
produced by all $X$. campestris pv. campestris mutants were significantly lower than that estimated for the WT strain, indicating that all $X$. campestris pv. campestris mutants formed more compact, flat, and homogeneous biofilms than $\mathrm{XcFc} 2$ (Table 2). These observations strongly indicate that different modifications in xanthan structure clearly affect the biofilm architecture of the $X$. campestris pv. campestris mutants.

Ketal-Pyr substituents and $\mathrm{Man}_{\text {ext }}$ residues of xanthan molecules are required for $X$. campestris pv. campestris virulence in Arabidopsis thaliana plants.

To test whether alterations in xanthan structure affect $X$. campestris pv. campestris virulence, we performed infection bioassays in A. thaliana with the different $X$. campestris pv. campestris mutants and analyzed their ability to colonize plants.

Consistent with previous reports (Aslam et al. 2008; Yun et al. 2006), at 4 days postinoculation (dpi), the WT strain XcFC2 was able to infect $A$. thaliana leaves and to induce disease symptoms, while infection with the xanthan-defective strain Xc1231 did not progress, causing no visible symptoms. XcL and XcI mutants caused considerably fewer symptoms and exhibited a lower bacterial growth inside the plant than the WT strain, while XcG behaved similarly to XcFC2, both in terms of bacterial growth and induction of disease symptoms. In contrast, $\mathrm{XcF}$ also showed a bacterial growth similar to that of $\mathrm{XcFC} 2$ but produced weaker symptoms in leaves than the WT strain (Fig. 3A and D).

Next, we tested the ability of XanWT to restore the virulence of $X$. campestris pv. campestris mutants. For this purpose, we pretreated A. thaliana leaves with XanWT $24 \mathrm{~h}$ prior to bacterial infection. At 4 dpi, XanWT was able to improve bacterial growth of all $X$. campestris pv. campestris mutants but not to the same extent as the similarly treated WT XcFC2 (Fig. 3B and $\mathrm{E})$. The extra growth of XcFC2 is likely explained by the extra amount of xanthan available to this strain due to its endogenous synthesis. These results are consistent with the symptoms observed and show the importance of xanthan modifications for disease progression.

We also explored the ability of the different SV-Xan to restore the virulence of the xanthan-defective strain Xc1231. To achieve this goal, we pretreated $A$. thaliana leaves with the
XcFC2 (WT)
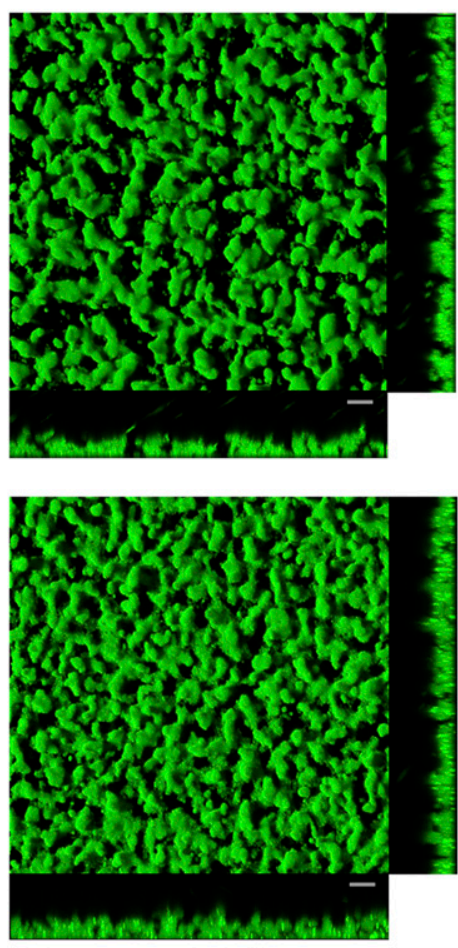

XcG
Xc1231
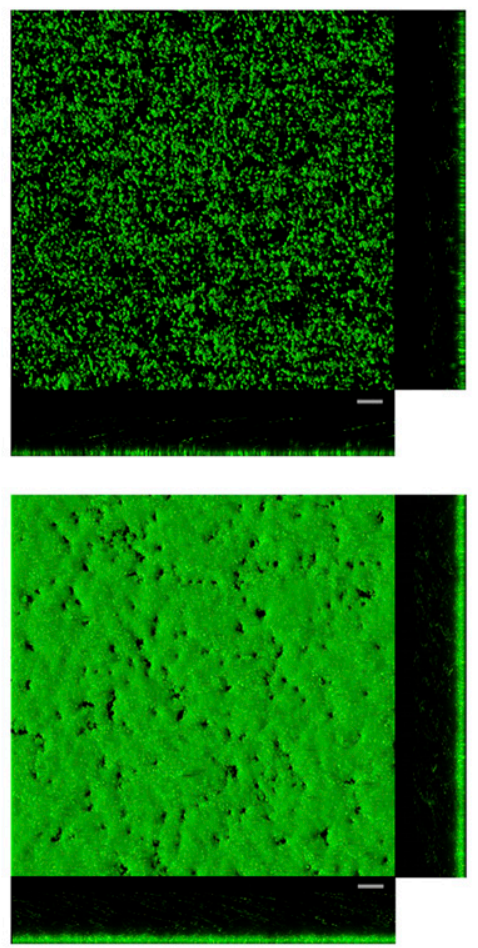

$\mathrm{Xcl}$
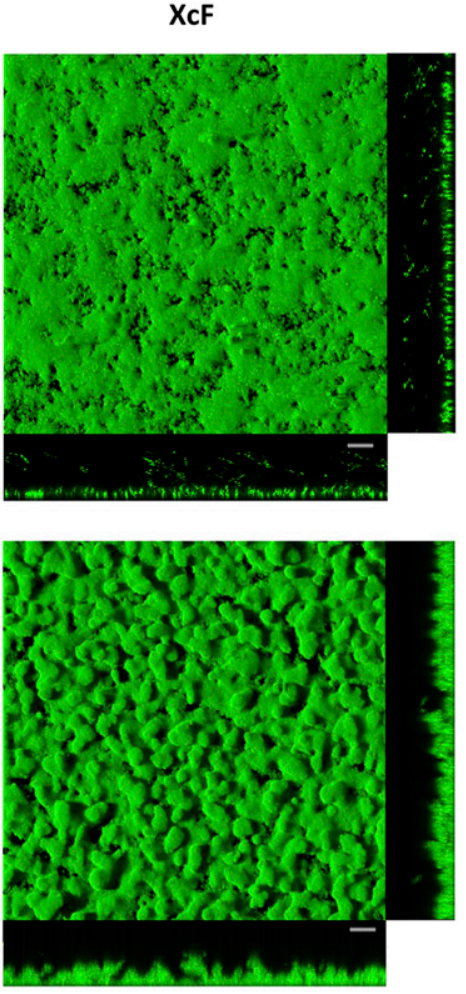

XcL

Fig. 2. Biofilm architecture. Green fluorescent protein-labeled Xanthomonas campestris pv. campestris cells grown on chambered covered slides and visualized under confocal laser scanning microscopy after $72 \mathrm{~h}$ of incubation. Square panels show the biofilm on the $x$ and $y$ planes, while bottom and right rectangles show the biofilm on the $z$ plane. Scale bars represent $10 \mu \mathrm{m}$.

Table 2. Evaluation of biofilm properties by COMSTAT ${ }^{\mathrm{a}}$

\begin{tabular}{lcccc}
\hline Strain & Average thickness $(\boldsymbol{\mu m})$ & Biomass $\left(\boldsymbol{\mu m}^{\mathbf{3}} / \boldsymbol{\mu m}^{\mathbf{2}}\right)$ & Roughness coefficient (arbitrary units) & Average diffusion distance $(\boldsymbol{\mu m})$ \\
\hline $\mathrm{XcFC} 2$ & $11.025 \pm 0.29 \mathrm{ab}$ & $8.590 \pm 0.156 \mathrm{ab}$ & $0.560 \pm 0.014 \mathrm{a}$ & $2.850 \pm 0.212 \mathrm{c}$ \\
$\mathrm{XcF}$ & $8.660 \pm 0.933 \mathrm{~b}$ & $7.985 \pm 0.690 \mathrm{~b}$ & $0.125 \pm 0.007 \mathrm{c}$ & $5.100 \pm 0.424 \mathrm{~b}$ \\
$\mathrm{XcG}$ & $13.705 \pm 0.997 \mathrm{a}$ & $10.885 \pm 0.884 \mathrm{a}$ & $0.265 \pm 0.007 \mathrm{~b}$ & $3.320 \pm 0.453 \mathrm{bc}$ \\
$\mathrm{XcL}$ & $9.465 \pm 0.403 \mathrm{~b}$ & $8.755 \pm 0.134 \mathrm{ab}$ & $0.240 \pm 0.057 \mathrm{~b}$ & $4.250 \pm 0.495 \mathrm{bc}$ \\
$\mathrm{XcI}$ & $10.535 \pm 1.082 \mathrm{ab}$ & $10.210 \pm 0.976 \mathrm{ab}$ & $0.084 \pm 0.002 \mathrm{c}$ & $7.765 \pm 0.898 \mathrm{a}$ \\
\hline
\end{tabular}

${ }^{a}$ All data represent the mean \pm standard deviation from two independent experiments. Different letters indicate significant differences $(P<0.05)$ based on the Tukey test. Measurements of average thickness, total biomass, roughness coefficient, and average diffusion distance of 72-h-old biofilm. 
different SV-Xan for $24 \mathrm{~h}$ before infecting with the xanthandeficient strain Xc1231. Pretreatment with SV-XanL and SVXanI failed to improve Xc1231 infection at 4 dpi. By contrast, SV-XanF and SV-XanG rescued Xc1231 growth in planta (Fig.
3C and F) but to a lesser extent than pretreatment with XanWT (Fig. 3A, B and C). These results suggest that Man $_{\text {ext }}$ residues and ketal-Pyr substituents are involved in virulence of $X$. campestris pv. campestris.

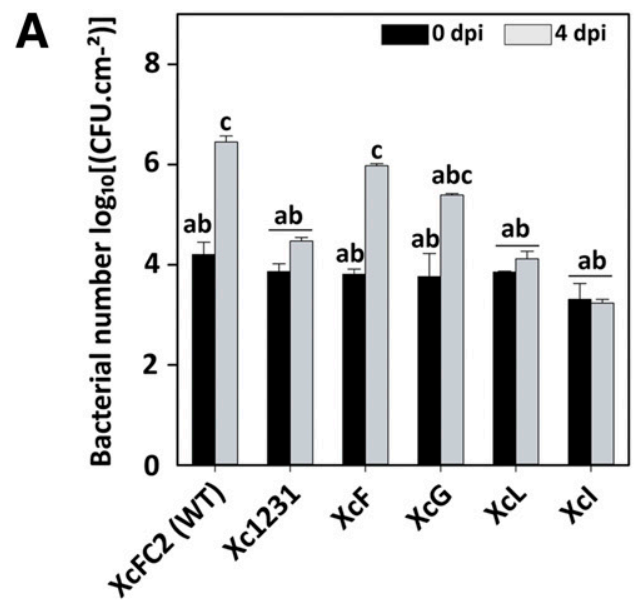

D

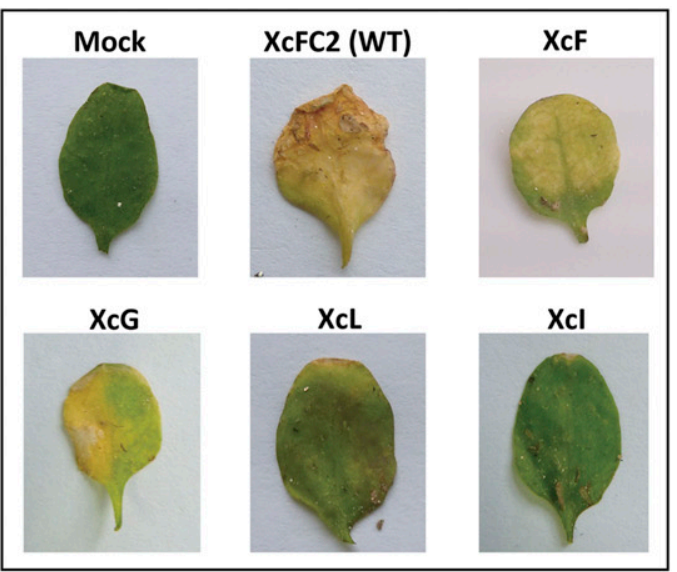

B

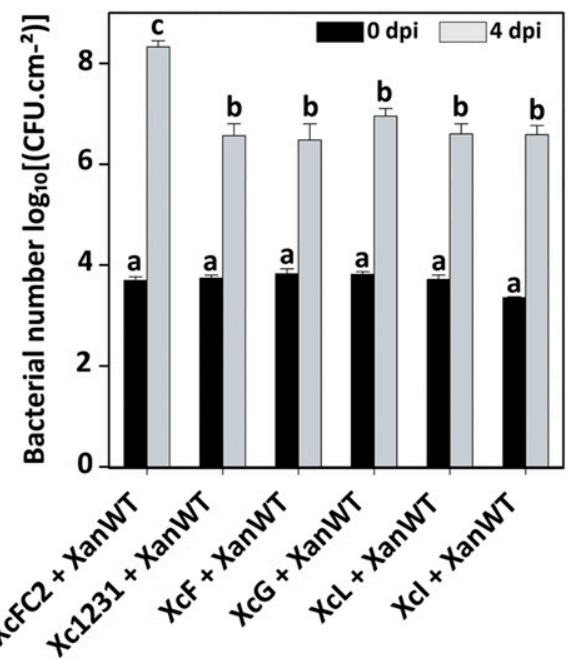

C

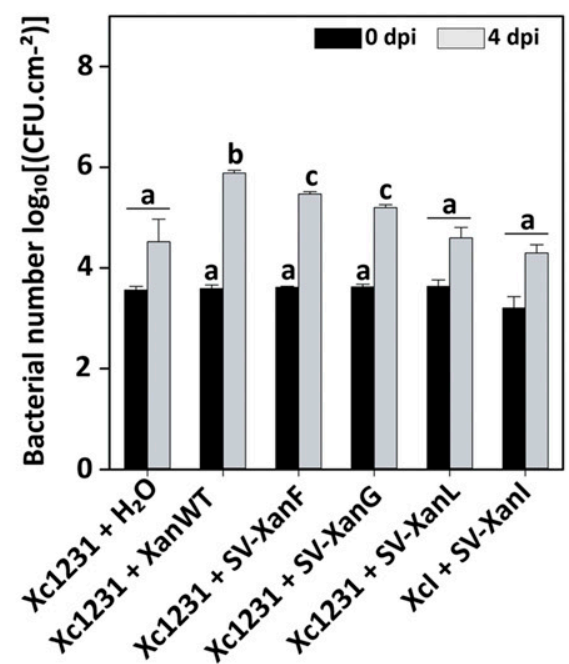

$\mathbf{E}$

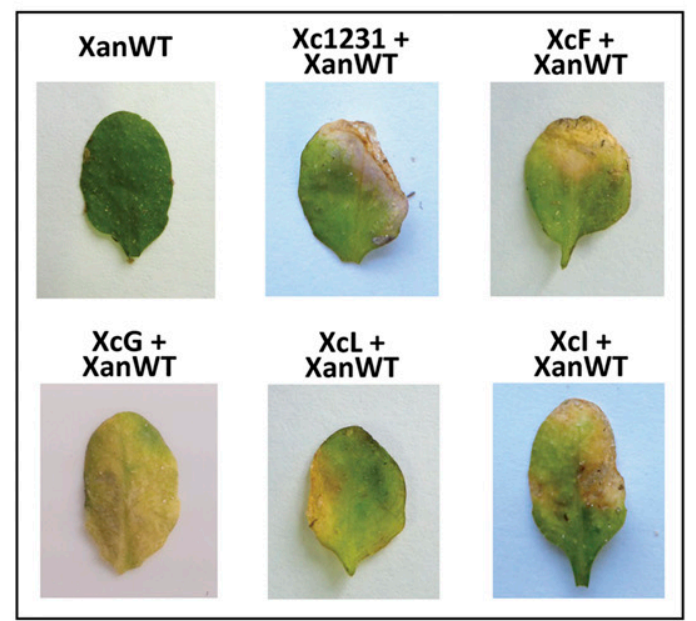

$\mathbf{F}$

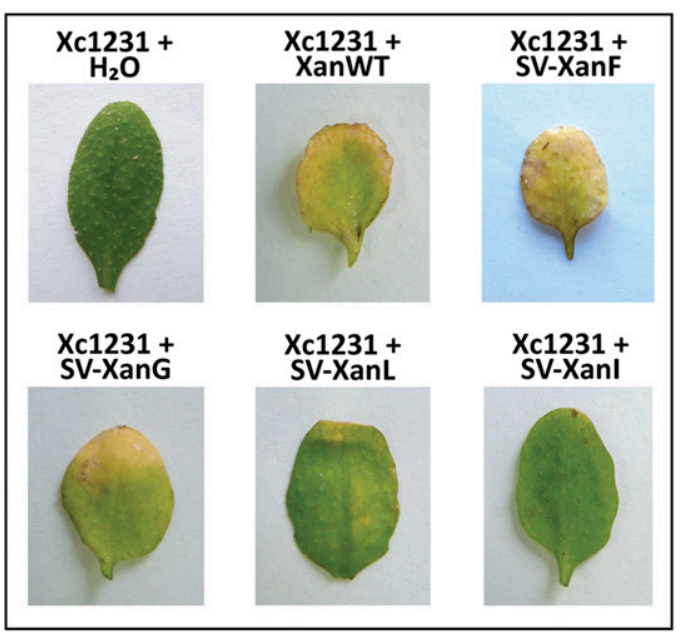

Fig. 3. Bacterial growth and symptoms developed by Xanthomonas campestris pv. campestris mutants in Arabidopsis thaliana infection assays. A and D, Bacterial growth and symptoms in plants infiltrated with $X$. campestris pv. campestris mutants. B and $\mathbf{E}$, Growth of X. campestris pv. campestris mutants and symptoms in plants treated $24 \mathrm{~h}$ before infection with xanthan produced by the wild-type strain (XanWT) at the rate of $200 \mu \mathrm{g} \mathrm{ml}^{-1}$. $\mathbf{C}$ and $\mathbf{F}$, Xc1231 growth and symptoms in plants pretreated with different structural variants of xanthan (SV-Xan) at the rate of $200 \mu \mathrm{g} \mathrm{ml} \mathrm{l}^{-1}$ for $24 \mathrm{~h}$ before infection. In all cases, infections were carried out with $10_{6} \mathrm{CFU} \mathrm{ml^{-1 }}$ of bacterial suspensions. Bacterial growth assessed immediately after infection (black bars) and 4 days postinoculation (dpi) (gray bars). Each bar represents the mean and standard deviation of two independent experiments with two replicates each. Different letters indicate significant differences (two-way analysis of variance, $P<0.05$ ) based on the Bonferroni test. 
Lack of ketal-Pyr substituents and Man $_{\text {ext }}$ residues of xanthan impairs its ability to suppress flg22-induced callose deposition in A. thaliana plants.

Callose deposition is an important defense mechanism that occurs after pathogens or their MAMPs are perceived by plants (Adam and Somerville 1996; Bestwick et al. 1995; Hann and Rathjen 2007). This response attenuates pathogen entry and growth and is required for disease resistance. It has been previously demonstrated that callose deposition is supressed during X. campestris pv. campestris infection (Rigano et al. 2007b; Yun et al. 2006). Therefore, to examine the ability of the different SV-Xan to interfere with callose deposition, we pretreated A. thaliana leaves with the different SV-Xan and, $24 \mathrm{~h}$ later, treated them with flg22.

It has been previously reported that xanthan is able to suppress flg22-induced callose deposition by $\mathrm{Ca}^{2+}$ chelation and not by blocking of flg22 or of its access to receptors (Aslam et al. 2008). Our results showed that SV-XanF and SV-XanG were able to suppress flg22-induced callose deposition in a similar extent to XanWT, whereas SV-XanL and SV-XanI were not (Fig. 4). These results suggest that ketal-Pyr substituents of $\mathrm{Man}_{\text {ext }}$ are the mainly responsible for the suppressive effect of xanthan on callose deposition, while the negative charges provided by GlcA residues seem to be not sufficient to chelate $\mathrm{Ca}^{2+}$ and to inhibit callose synthase activity.

\section{Xanthan prevents flg22- and ABA-induced} stomatal closure.

Stomatal closure can act as an effective barrier during $X$. campestris pv. campestris infection (Gudesblat et al. 2009; Sawinski et al. 2013). Stomatal closure induced by ABA requires $\mathrm{Ca}^{2+}$ influx into the cytosol from the apoplasts and, hence, can be inhibited through $\mathrm{Ca}^{2+}$ chelation with EGTA (Kollist et al. 2014; Webb et al. 1996). Since it has been previously reported that xanthan induces plant susceptibility through $\mathrm{Ca}^{2+}$ chelation (Aslam et al. 2008), we speculated that it might also inhibit stomatal closure. Therefore, we tested the ability of XanWT to interfere with stomatal closure triggered by $\mathrm{ABA}$ or flg22 in A. thaliana. XanWT was able to partially inhibit both ABA- and flg22-induced stomatal closure at concentrations starting from 10 and $30 \mu \mathrm{g} \mathrm{ml}^{-1}$, respectively, and in a dose-dependent manner (Fig. 5A and B). These results suggest that $\mathrm{Ca}^{2+}$ chelation by xanthan is sufficient to inhibit stomatal closure, as previously reported for EGTA (Webb et al. 1996).

To evaluate the importance of xanthan structure in the modulation of stomatal movements, we measured the effect of the different SV-Xan on the Xc1231-induced stomatal closure in A. thaliana epidermis. At $1 \mathrm{~h}$ postincubation, xanthan was also able to inhibit stomatal closure triggered by the xanthandeficient strain Xc1231 (Fig. 5C). XanWT and SV-XanF inhibited the Xc1231-induced stomatal closure at similar levels, while SV-XanL and SV-XanI showed a markedly reduced inhibitory effect on Xc1231-induced stomatal closure (Fig. 5C). SV-XanG also inhibited Xc1231-induced stomatal closure but not to the level reached by XanWT (Fig. 5C). These results suggest that modifications in xanthan structure seriously affect its ability to suppress stomatal closure, principally by the lack of ketal-Pyr groups and $\mathrm{Man}_{\mathrm{ext}}$ residues. To confirm these results, we performed an additional assay in which we analyzed the effect of the different SV-Xan on flg22-mediated stomatal closure, in the absence of bacteria. While the different SV-Xan failed to promote stomatal closure when applied alone, XanWT, SV-XanF, and SV-XanG severely affected flg22-triggered stomatal closure, but SV-XanL and SV-XanI showed a markedly reduced inhibitory effect on flg22-induced stomatal closure (Fig. 5D). These results suggest that the presence and pyruvilation of $\mathrm{Man}_{\mathrm{ext}}$ residues are required for xanthan to prevent stomatal closure.

\section{DISCUSSION}

Bacterial polysaccharides represent a diverse range of macromolecules with functions that range from structural cell-wall components to important virulence factors (Ullrich 2009). Xanthan has been shown to suppress plant defenses (Aslam
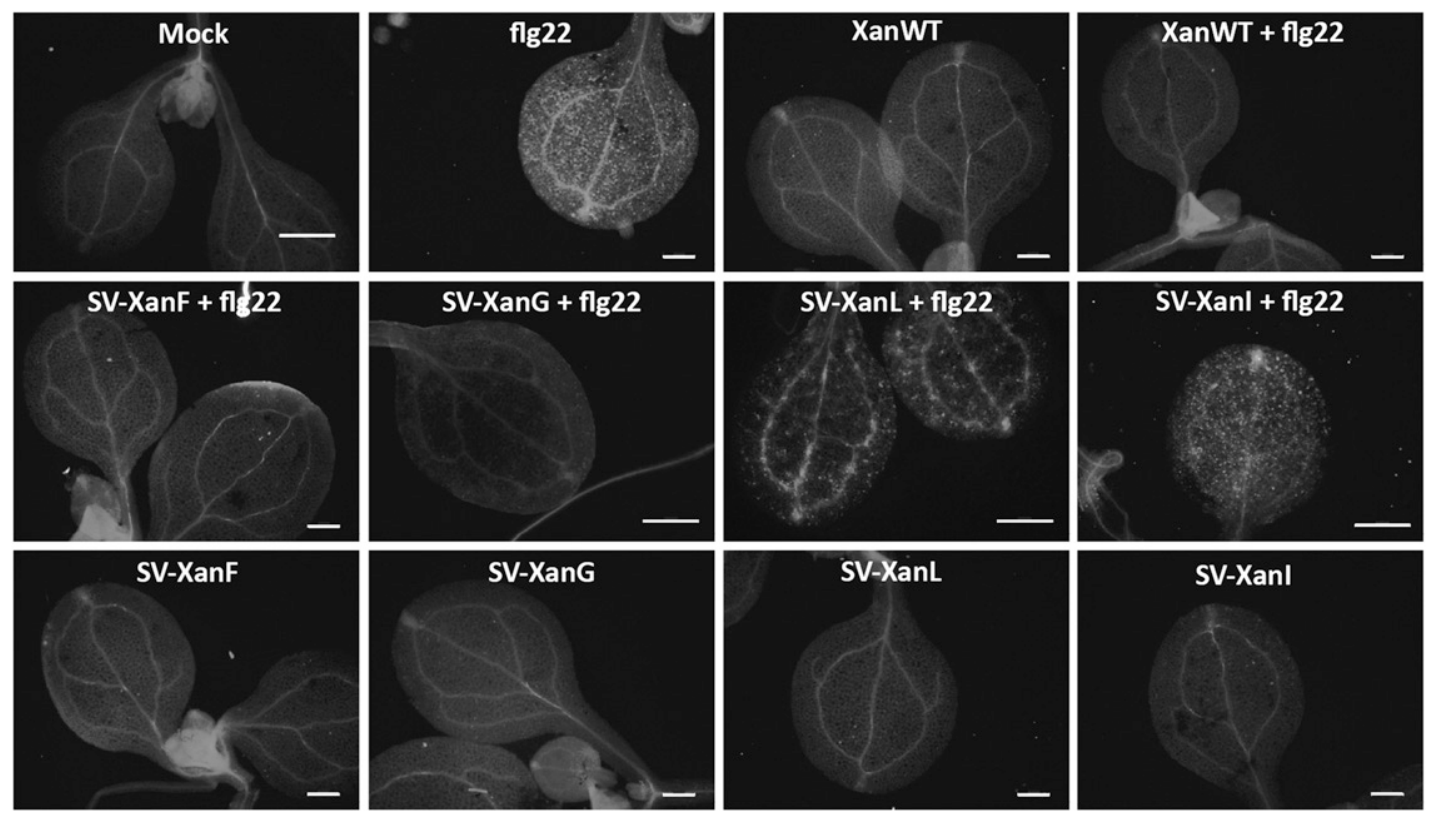

Fig. 4. Ketal-pyruvate substituents and $\operatorname{Man}_{\text {ext }}$ (a second terminal mannose) residues are required for suppression of callose deposition. Callose deposition was analyzed by aniline blue staining and was examined with a stereo epifluorescence microscope 24 h postinoculation of 10 -day-old Arabidopsis thaliana seedlings with $1 \mu \mathrm{M}$ flg22. Plants were pretreated with xanthan produced by the wild-type strain (XanWT) and different structural variants of xanthan (SV-Xan) produced by the different mutant strains $\left(200 \mu \mathrm{g} \mathrm{ml}^{-1}\right)$ for $24 \mathrm{~h}$ before elicitation of callose deposition by flg $22(1 \mu \mathrm{M})$. Images are representative of three independent trials, in which at least five fields were observed for each treatment. White dots indicate callose deposition. White scale bars represent $20 \mu \mathrm{m}$. 
et al. 2008; Yun et al. 2006) and appears to be essential to initiate cell attachment and to determine biofilm architecture of $X$. campestris pv. campestris and $X$. citri pv. citri during the infective process (Dow et al. 2003; Rigano et al. 2007a; Torres et al. 2007). Xanthan is also important for bacterial epiphytic survival before colonization of intercellular spaces of the host plant and for attachment to xylem vessels (Stoodley et al. 2002). Moreover, it has been suggested that shortening of xanthan repetitive units to four sugars or inactivation of enzymes that add acetyl substituents to the xanthan molecules may reduce the symptoms caused by $X$. campestris pv. campestris on Brassica oleracea cv. Braunschweiger (Katzen et al. 1998). However, the precise mode of action of xanthan as a virulence factor is still not well understood.

It has been recently shown that EPSs are needed to form an intricate and complex three-dimensional matrix, whose architecture creates various microenvironments that allow interactions between bacteria and are essential for expression of virulence (Xiao et al. 2012). It has also been reported that GlcA residues or ketal-Pyr groups present in the EPSs allow the association of $\mathrm{Ca}^{2+}$ to increase binding forces in a mature biofilm ( $\mathrm{Vu}$ et al. 2009). In this work, we performed further studies aimed to understand the structural basis of the role of xanthan in $X$. campestris pv. campestris virulence and host defense and investigated whether modifications in xanthan composition and structure could affect bacterial adhesion, biofilm formation or architecture, and plant-pathogen interaction.

The four $X$. campestris pv. campestris mutants analyzed were less virulent and produced less EPS than the WT strain XcFC2. However, although the $X$. campestris pv. campestris mutants that produced the lowest amount of EPS were those that showed the lowest bacterial adhesion, the amount of EPS was not the only factor responsible for the lower bacterial adhesion (Table 3). Cultures of the xanthan-deficient strain Xc1231 in medium supplemented with comparable amounts of the different SV-Xan showed that the different EPSs improved
A

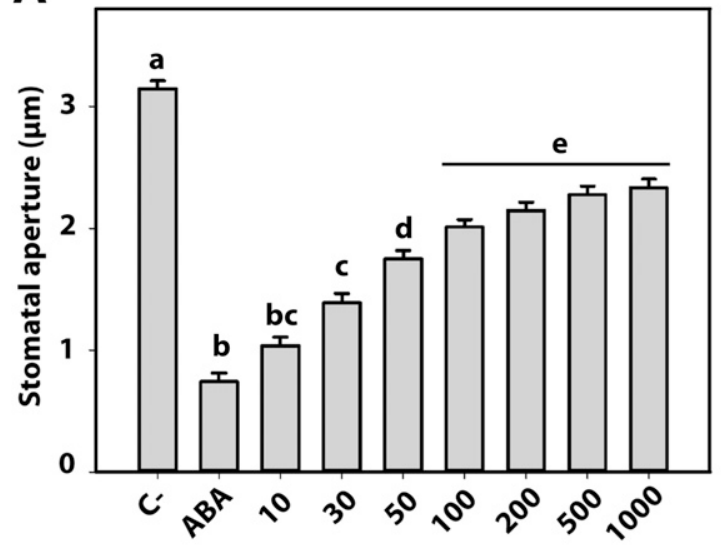

XanWT concentration $\left(\mu \mathrm{g} \cdot \mathrm{mL}^{-1}\right)$

C

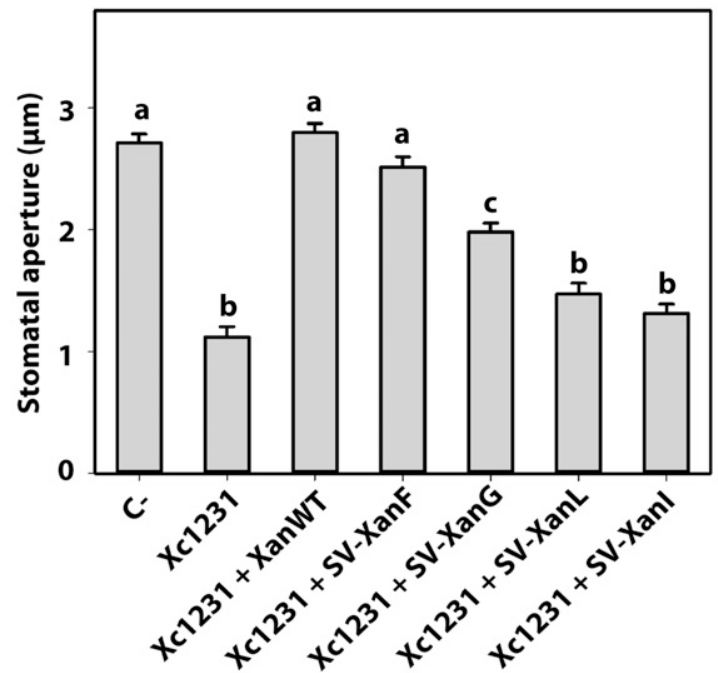

B

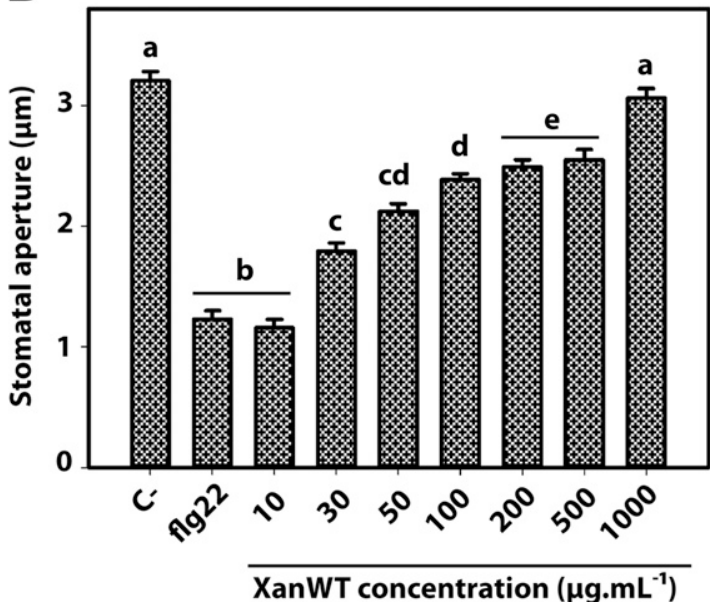

D

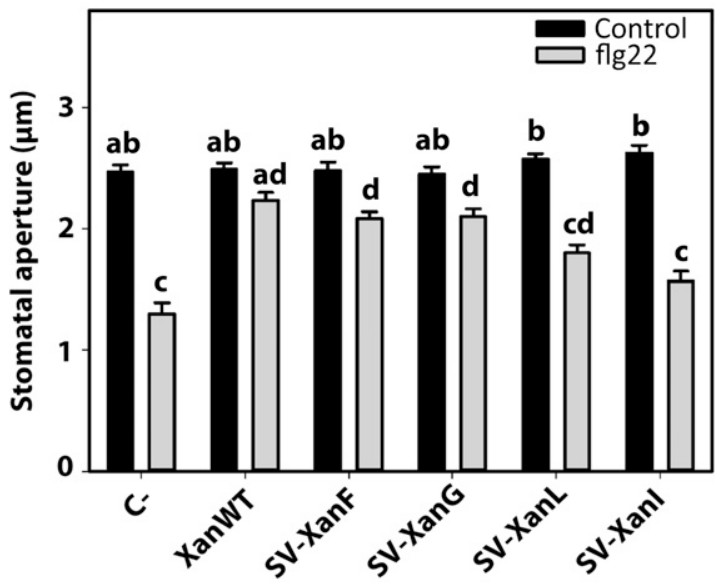

Fig. 5. Xanthan partially prevents stomatal closure triggered by bacteria, flg22, and abscisic acid (ABA) only when ketal-pyruvate substituents and Man ext $_{\text {(a }}$ second terminal mannose) residues are present. A and B, Xanthan produced by the wild-type strain (XanWT) inhibited stomatal closure in response to ABA $(20 \mu \mathrm{M})$ or flg22 $(5 \mu \mathrm{M})$ in a dose-dependent manner. C, Inhibition of Xc1231-induced stomatal closure by different structural variants of xanthan (SV-Xan) $\left(200 \mu \mathrm{g} \mathrm{ml}^{-1}\right)$. Bacteria were used at $5.10^{8} \mathrm{CFU}$ per milliliter and apertures were measured after $1 \mathrm{~h}$ of incubation. $\mathbf{D}$, Inhibition of stomata closure triggered by flg22 $(5 \mu \mathrm{M})$ by different SV-Xan. In all panels, $C$ - indicates mock-treated samples. In A, B, and D, the exopolysaccharides were added $1 \mathrm{~h}$ prior to ABA and flg22 treatments. In $\mathrm{C}$, the different SV-Xan were added simultaneously with Xc1231. Stomatal apertures were measured $1.5 \mathrm{~h}$ after application of the respective treatments in $\mathrm{A}, \mathrm{B}$, and $\mathrm{D}$. Different letters indicate significant differences at $P<0.01$ in $\mathrm{A}, \mathrm{B}$, and C (one-way analysis of variance [ANOVA], Tukey test) and at $P<0.05$ in D (two-way ANOVA, Bonferroni test). Error bars represent standard error from two (A, B, C) and three (D) independent trials, $n=40$ per trial in all experiments. Mock treatments were performed with the 10:10 buffer. 
Xc1231 adhesion, following a pattern similar to that displayed by the $X$. campestris pv. campestris mutant producing each SVXan. Therefore, we inferred that the absence of certain xanthan components, which modify the binding forces involved in xanthan structure, affected $X$. campestris pv. campestris adhesion independently of the amount of EPS synthesized by each mutant.

Adhesion assays showed that when xanthan molecules lack ketal-Pyr groups, $\mathrm{Man}_{\mathrm{ext}}$ residues, or acetyl groups that decorate the $\mathrm{Man}_{\mathrm{int}}(\mathrm{XcL}, \mathrm{XcI}$, and $\mathrm{XcF}$, respectively), they showed lower adhesion. These results are in accordance with previous studies, which reported that the components of EPS can influence the extent to which microorganisms adhere to different surfaces and that EPS formation leads to irreversible adhesion to different environmental surfaces (Donlan 2002; Romaní et al. 2008; van Hullebusch et al. 2003). Moreover, the biofilms produced by $\mathrm{XcF}, \mathrm{XcL}$, and $\mathrm{XcI}$ exhibited architectures different from the one formed by XcFC2, suggesting that xanthan composition and structure is relevant to build the biofilm matrix. EPS also promotes events that facilitate the establishment of microcolonies encased in EPS, which may serve as architectural units that become connected during biofilm construction, forming compartmentalized networks that confer highly heterogeneous yet cohesive environments within the threedimensional architecture (Xiao et al. 2012).

In the particular case of $\mathrm{XcF}$, this mutant synthesizes an EPS without acetyl groups in the $\mathrm{Man}_{\text {int }}$. This change in SV-XanF composition and structure showed an impact on bacterial adhesion as well as on biofilm architecture. $\mathrm{XcF}$ formed a more compact and homogeneous biofilm than that developed by $\mathrm{XcFC} 2$. Because the acetyl groups allow the trisaccharide side chains of xanthan to align with the backbone, stabilizing the overall molecule, their lack leads to more disordered EPS strands (Dentini et al. 1984; Shatwell et al. 1990). The more disordered structure of this SV-XanF regarding the XanWT might enhance the gel formation in the biofilm matrix, which could increase the strength of its architecture, according to a report by Villain-Simonnet et al. (2000). Therefore, a biofilm in which the EPSs form a relatively rigid gel could remain bacteria-immobilized in contrast to a biofilm in which its architecture is relatively fluid and allows redistribution of bacteria within the matrix during bacterial growth and biofilm development (Møller et al. 1998). In line with our results, it has been proposed that the acetyl groups of alginate are necessary to mediate cell aggregation and to determine the heterogeneous architecture of mature biofilm of Pseudomonas aeruginosa, which is attributed to the ability of acetyl groups to increase the adhesive and cohesive properties of alginate (Franklin and Ohman 1993; Tielen et al. 2005). These observations are consistent with the fact that $\mathrm{XcF}$ developed a more homogeneous and compact biofilm than the WT strain. Interestingly, although the lack of $\mathrm{Man}_{\text {int }}$ acetylation affected bacterial adhesion and biofilm architecture, it seems to have had only a weak impact on $\mathrm{XcF}$ virulence, since the symptoms produced by this strain in A. thaliana were barely weaker than those of XcFC2 and its growth was similar to that of the WT strain.

$\mathrm{XcG}$ synthesizes an EPS without acetyl groups in the $\mathrm{Man}_{\text {ext }}$. Contrary to that observed for $\mathrm{XcF}$, this change in SV-XanG composition and structure showed no significant differences in bacterial adhesion or in biofilm architecture relative to the WT strain. Moreover, the lack of acetyl groups in $\mathrm{Man}_{\mathrm{ext}}$ residues also seems to have no effect on $\mathrm{XcG}$ virulence on $A$. thaliana. This could be explained by either the degree of acetylation of $\mathrm{Man}_{\text {ext }}$ residues, the position of these nonglycosidic groups in the xanthan molecule, or both. It is known that approximately $90 \%$ of $\mathrm{Man}_{\text {int }}$ residues can be acetylated, while the proportion in which the $\mathrm{Man}_{\text {ext }}$ can be acetylated is lower, probably because of the presence of ketal-Pyr groups (Cadmus et al. 1976; Stankowski et al. 1993). As for the position of acetyl groups, those that decorate the $\mathrm{Man}_{\text {ext }}$ are farther from the backbone than those that substitute the $\mathrm{Man}_{\mathrm{int}}$, therefore having a lesser chance to interact with it. Thus, this could be why the lack of $\mathrm{Man}_{\text {ext }}$ acetylation did not affect XcG biofilm architecture or virulence.

The most drastic effects on the biofilm architecture were observed in XcL and XcI mutants. XcL synthesizes an EPS without ketal-Pyr groups in the $\mathrm{Man}_{\mathrm{ext}}$. This change in SVXanL had a large impact on adhesion, biofilm architecture, and virulence of this mutant strain. The architecture of the biofilm formed by $\mathrm{XcL}$ was more compact and homogeneous than that of XcFC2. This result was expected because of the absence of ketal-Pyr substituents in SV-XcL. According to Dentini et al. (1984), the absence of ketal-Pyr groups causes a decrease in intramolecular electrostatic repulsions and in the ability of EPS to hydrate and to interact with other molecules in the biofilm matrix, thus leading to a more homogeneous and compact biofilm. Consistently with the effect of XcL on biofilm architecture, its virulence was also strongly reduced, as plants infected with this strain showed considerably fewer symptoms and exhibited lower bacterial growth inside the host than the WT strain.

In the case of XcI, the absence of $\mathrm{Man}_{\text {ext }}$ largely affected bacterial adhesion and biofilm architecture as well as its virulence. The biofilm developed by $\mathrm{XcI}$ is much more compact and homogeneous than that of $\mathrm{XcFC} 2$ as well as than those of the other $X$. campestris pv. campestris mutants. This, coupled to the fact that SV-XanI production is very slow, severely impairs the ability of XcI to survive, grow, and develop visible symptoms in A. thaliana. Interestingly, the diminished amount of EPS produced by XcI plus the lack of $\mathrm{Man}_{\text {ext }}$ affected in a more severe manner the biofilm architecture and bacterial virulence in $\mathrm{XcI}$ than did the lack of ketal-Pyr groups in XcL.

When we studied the induction of defense responses by different SV-Xan, we observed that the lack of $\mathrm{Man}_{\text {int }}$ or Man $\mathrm{Mxt}_{\mathrm{ext}}$ acetylation did not affect the ability of SV-XanF or SV-XanG, respectively, to prevent callose deposition. In both cases, the

Table 3. Arbitrary quantification of some results observed in this work based on data obtained in each experiment ${ }^{\mathrm{a}}$

\begin{tabular}{|c|c|c|c|c|c|c|}
\hline Parameter & Xc1231 & $\mathrm{XcFC2}(\mathrm{WT})$ & $\mathrm{XcF}$ & XcG & XcL & XcI \\
\hline $\begin{array}{l}\text { Relative exopolysaccharide amount } \\
\text { produced in respect to the WT strain }\end{array}$ & ND & $100 \% \mathrm{~d}$ & $73 \% \mathrm{~b}$ & $86 \% \mathrm{c}$ & $83 \% \mathrm{c}$ & $8 \%$ a \\
\hline Bacterial adhesion & $+\mathrm{a}$ & $+++++\mathrm{d}$ & $+++\mathrm{bc}$ & $++++c d$ & +++ bc & $++b$ \\
\hline Symptoms in Arabidopsis thaliana at $4 \mathrm{dpi}$ & ND & +++++ & +++ & +++ & + & ND \\
\hline $\begin{array}{l}\text { Xanthomonas campestris pv. campestris } \\
\text { growth in } A \text {. thaliana at } 4 \mathrm{dpi}\end{array}$ & $++a b$ & $+++++\mathrm{c}$ & $++++\mathrm{c}$ & $+++a b c$ & $++\mathrm{ab}$ & $++\mathrm{ab}$ \\
\hline Callose deposition in $A$. thaliana ${ }^{\mathrm{b}}$ & NA & ND & ND & ND & ++++ & ++++ \\
\hline
\end{tabular}

${ }^{a}$ Letters between parenthesis indicate differences based on the respective statistical analysis. WT $=$ wild type; dpi $=$ days postinoculation; $\mathrm{NA}=$ not analyzed; $\mathrm{ND}=$ not detected.

${ }^{\mathrm{b}}$ Callose deposition after pretreatment with the different exopolysaccharides and treatment with flg22. 
negative charges were intact and, therefore, these EPSs should be able to chelate $\mathrm{Ca}^{2+}$ and suppress the plant immune response, in which $\mathrm{Ca}^{2+}$ influx into the cytosol is involved. Consistently, XcF and XcG successfully infected A. thaliana. In the cases of $\mathrm{XcL}$ and $\mathrm{XcI}$, the absence of negative charges provided by the ketal-Pyr groups likely affected the ability of SV-XanL and SV-XanI to chelate $\mathrm{Ca}^{2+}$ and, hence, to suppress callose deposition. Therefore, SV-XanL and SV-XanI were less able to partially inhibit callose deposition as part of the immune response mechanisms, thus allowing the host to build defenses in response to infection.

On the other hand, considering that $\mathrm{Ca}^{2+}$ is involved in the signaling cascade that leads to stomatal closure (Sirichandra et al. 2009) and that xanthan is able to chelate this cation, modifying its cytosolic availability inside the host (Aslam et al. 2008 ), we propose that the ability of xanthan to chelate $\mathrm{Ca}^{2+}$ could contribute to modulating stomatal closure. To analyze stomatal aperture in the presence of xanthan, we analyzed a concentration range of XanWT (10 to $1,000 \mu \mathrm{g} \mathrm{ml}^{-1}$ ), which included xanthan concentrations analyzed by Yun et al. (2006) for $X$. campestris pv. campestris infection assays. We observed that stomatal reopening in the presence of XanWT was larger for flg22-induced than for ABA-induced stomatal closure. $\mathrm{Ca}^{2+}$ oscillations in ABA-induced stomatal closure are only some of the multiple signaling components activated by this phytohormone that lead to stomatal closure (Sirichandra et al. 2009). Therefore, the differences in stomatal reopening between ABA and flg22 suggest that $\mathrm{Ca}^{2+}$ chelation during flg22-triggered stomatal closure is more relevant than $\mathrm{Ca}^{2+}$ chelation during ABA-induced closure. We attribute this to the fact that, in ABA-induced closure, several signaling components act in a redundant manner, leading to a more pronounced closure, even in the presence of EPS. Here, we demonstrated that XanWT contributed to stomatal closure and changes in its structure affected its ability to modulate stomatal movements.

Coincubation of $A$. thaliana epidermis in the presence of flg22 and the different SV-Xan showed that the lack of ketalPyr groups (SV-XanL) and $\mathrm{Man}_{\text {ext }}(\mathrm{SV}-\mathrm{XanI})$ strongly affected the ability of EPS to prevent flg22-triggered stomatal closure. Similar results were observed when stomatal closure was induced by Xc1231. On the other hand, coincubation of $A$. thaliana epidermis in the presence of flg22 or Xc1231 and the different SV-Xan showed that SV-XanF prevented stomatal closure at a level similar to XanWT. In the particular case of SV-XanG, it was able to suppress the Xc1231-induced stomatal closure but not to the level reached by XanWT. However, when we analyzed the flg22-induced stomatal closure in the absence of bacteria, we observed that SV-XanG was able to suppress stomatal closure at a level similar to XanWT. Therefore, it is possible that components of Xc1231 culture or secreted by the bacteria could be interfering with the effect of EPS on stomatal closure. For this reason, we also performed assays in the absence of bacteria, using a MAMP as flg22 to analyze the effect of the EPS on stomatal closure.

The ability of the different SV-Xan to prevent stomatal closure supported previous experiments showing that the absence of ketal-Pyr groups as well as of Man $_{\text {ext }}$ affected xanthan capacity to interfere with stomatal defense. This could be explained by the ability of the negative charges provided by the ketal-Pyr groups to chelate $\mathrm{Ca}^{2+}$, essentially resulting in diminishing the availability of $\mathrm{Ca}^{2+}$ and affecting the plant response. While it has been previously shown that X. campestris pv. campestris secretes a small compound capable of reopening stomata (Gudesblat et al. 2009), inhibition of its closure by xanthan could be a second mechanism that might act in concert with the first one to overcome stomatal immunity.

In summary, the lower adhesion and the more compact biofilms developed by XcL and XcI compared with the WT strain, as well as the inability of these strains to suppress host defense responses and to develop disease symptoms in A. thaliana, suggest that ketal-Pyr groups are essential for xanthan function in $X$. campestris pv. campestris pathogenesis. This can be explained by the ability of the negative charges of ketal-Pyr groups to chelate $\mathrm{Ca}^{2+}$. Our results are in line with those reported by Bergmann et al. (2008), who proposed that the negative charges provided by ketal-Pyr groups are the principal binding sites of cations, while those provided by GlcA residues do not take part in cation chelation.

Further studies should be carried out to analyze how the biofilm architectures developed by the different $X$. campestris pv. campestris mutants are affected in their resistance to conventional treatments against diseases caused by Xanthomonas spp., such as copper salts. Additionally, considering that the lack of both ketal-Pyr groups and $\mathrm{Man}_{\mathrm{ext}}$ residues of xanthan severely affected $X$. campestris pv. campestris virulence, their enzymatic removal could be an interesting strategy against diseases caused by Xanthomonas spp.

\section{MATERIALS AND METHODS}

\section{Growth conditions of bacterial strains.}

The strains and plasmids used in this study are listed in Table 4. Antibiotics were obtained from Sigma (St. Louis) and were added to the medium as required at the following concentrations (in micrograms per milliliter): rifampicin, 50; tetracycline, 10; kanamycin, 50; and gentamicin, 30.

Xanthomonas strains were cultured at $28^{\circ} \mathrm{C}$ with shaking at $200 \mathrm{rpm}$ in peptone-yeast extract-malt extract (PYM) medium (Cadmus et al. 1976) or Y minimal medium (YMM) (Sherwood 1970). To examine bacterial adhesion and biofilm development, bacteria were grown in YMM containing glucose $(1 \% \mathrm{wt} / \mathrm{vol})$ as the sole carbon source (Rigano et al. 2007a). Escherichia coli S17-1 (Table 4) was grown at $37^{\circ} \mathrm{C}$ and $200 \mathrm{rpm}$ in Luria Bertani medium (Sambrook and Russell 2001).

The construction of the $X$. campestris pv. campestris mutant strains used in this work has been reported by Katzen et al. (1998). In Supplementary Figure S3, we added a brief description of how they were constructed and a scheme of the $X$. campestris pv. campestris gum operon, indicating the mutated gum genes used in this work.

\section{In vivo xanthan production.}

To produce EPS, different $X$. campestris pv. campestris strains were grown in PYM medium at $28^{\circ} \mathrm{C}$ and $200 \mathrm{rpm}$ for 5 days. Xanthan was precipitated with two volumes of isopropanol and recovered by filtration on a stainless steel sieve. Wet xanthan fibers were washed with increasing concentrations of ethanol ( 75 to $96 \%$ ethanol in water), were dried at $55^{\circ} \mathrm{C}$, and were weighed to determine xanthan yield.

\section{Bacterial adhesion assay.}

The crystal violet technique was used to analyze bacterial adhesion to an abiotic surface (O'Toole and Kolter 1998). Briefly, bacterial strains were grown overnight in PYM medium and inoculated into YMM to an optical density at $600 \mathrm{~nm}$ $\left(\mathrm{OD}_{600}\right)$ of 0.1 . Aliquots of $150 \mu \mathrm{l}$ were used to fill wells of a microtiter plate and were then incubated at $28^{\circ} \mathrm{C}$ for $72 \mathrm{~h}$. To confirm similar bacterial growth, $\mathrm{OD}_{600}$ was measured before the adhesion assay. The medium was gently removed using a pipette; the microtiter plate was then washed with $0.9 \% \mathrm{NaCl}$ and was stained using $0.1 \%$ (wt/vol) crystal violet solution. After $30 \mathrm{~min}$ of incubation, the unbound crystal violet was removed and the wells were washed twice with distilled water. The crystal violet of each well was dissolved by adding $150 \mu \mathrm{l}$ $70 \%$ ( $\mathrm{vol} / \mathrm{vol})$ ethanol, and the absorbance was measured in a 
microplate reader at $570 \mathrm{~nm}\left(\mathrm{CV}_{570}\right)$. The adhesion value was normalized to the cell optical density. This value was termed relative adhesion $\left(\mathrm{CV}_{570} / \mathrm{OD}_{600}\right)$.

\section{In vitro analysis of biofilm formation observed by CLSM.}

$X$. campestris pv. campestris strains were transformed by conjugation as previously described (Simon 1984), using E. coli S17-1 carrying pBBR2-GFP. The plasmid pBBR2GFP is a derivative of pBBR1MCS-2 (Kovach et al. 1994, $1995)$ and carries the green fluorescent protein gene ( $g f p)$, which is constitutively expressed (Posadas et al. 2012).

For in vitro experiments, these strains were grown at $28^{\circ} \mathrm{C}$ on PYM supplemented with kanamycin. Aliquots of $500 \mu \mathrm{l}$ were transferred to chambered cover-glass slides containing a 1-mmthick borosilicate glass (LabTek, Nunc, Penfield, NY, U.S.A.), as previously described (Malamud et al. 2011). Cultures of each strain were diluted in YMM to a final $\mathrm{OD}_{600}$ of 0.004 and were grown in the chambers for $72 \mathrm{~h}$ at $28^{\circ} \mathrm{C}$.

Biofilm formation was monitored with an inverted microscope Nikon Eclipse TE 2000-E2 CLSM (Nikon, Melville, NY, U.S.A.). Three-dimensional images were generated with IMARIS 6.3.1 software (Bitplane, St. Paul, MN, U.S.A.) and, subsequently, were analyzed using COMSTAT Software Image Processing Toolbox, as previously described (Heydorn et al. 2000).

\section{Plant growth conditions and inoculations and bacterial growth assays.}

Plants of A. thaliana L. Heynh ecotype Columbia (Col-0) were grown in petri dishes containing half-strength Murashige and Skoog (MS) medium (Murashige and Skoog 1962) supplemented with $1 \%$ sucrose under a 12-h-light and 12-h-dark cycle (photon flux density of $90 \mu \mathrm{E}$ ) at 22 to $23^{\circ} \mathrm{C}$. One-weekold plants were transferred to a mixture of vermiculite, peat, and perlite $(1: 1: 1)$.

Different strains cultured in PYM medium were harvested by centrifugation, and pellets were washed and suspended in $10 \mathrm{mM} \mathrm{MgCl}_{2}$ at a concentration of $10^{6} \mathrm{CFU} \mathrm{ml}{ }^{-1}$, and then, were syringe-infiltrated into $A$. thaliana leaves. Symptoms were observed at 4 dpi and bacterial growth was quantified as previously described (Newman et al. 1994). Briefly, two samples were taken for each strain at $4 \mathrm{dpi}$, and leaf discs were surface-sterilized with $70 \%$ ethanol. Bacterial populations were quantified by macerating $0.6-\mathrm{cm}^{2}$ leaf discs in $0.5 \mathrm{ml}$ of $10 \mathrm{mM} \mathrm{MgCl}$, followed by dilution plating onto PYM with appropriate antibiotics. Plates were incubated at $28^{\circ} \mathrm{C}$, colonies were counted after $72 \mathrm{~h}$, and CFU per milliliter were calculated. Population data were transformed to $\log _{10}$ values, and standard deviations were determined.

\section{Callose deposition.}

Callose staining was performed as described before (Millet et al. 2010). Briefly, 10-day-old seedlings, grown in MS liquid medium in 12-well multiwell plates, were incubated with $200 \mu \mathrm{g}$ of each EPS per milliliter for $24 \mathrm{~h}$ and were then treated with $1 \mu \mathrm{M}$ flg22. After $24 \mathrm{~h}$, samples were fixed in a 3:1 ethanol/acetic acid solution for several hours. The fixative solution was changed several times to ensure both thorough fixing and clearing of the tissues. Seedlings were rehydrated in $70 \%$ ethanol for $2 \mathrm{~h}, 50 \%$ ethanol for an additional $2 \mathrm{~h}$, and in water overnight. After two or three washes with water, seedlings were treated with $10 \% \mathrm{NaOH}$ and were placed at $37^{\circ} \mathrm{C}$ for 1 to $2 \mathrm{~h}$ to further clarify the tissues. After three to four washes with water,

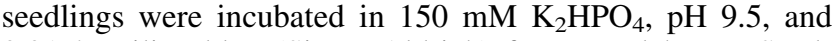
$0.01 \%$ aniline blue (Sigma-Aldrich) for several hours. Seedlings were mounted on slides and callose was observed as bright dots, using a Nikon Eclipse E600 epifluorescence microscope at 10 and 40× (excitation $390 \mathrm{~nm}$, emission $460 \mathrm{~nm}$ ).

\section{Stomatal aperture bioassays.}

Stomatal bioassays were performed as previously described (Gudesblat et al. 2009). Epidermal abaxial peels from leaves of 4-week-old plants were floated in 10:10 buffer $(10 \mathrm{mM} \mathrm{KCl}$ and $10 \mathrm{mM}$ MES-KOH, pH 6.15) under light for $2.5 \mathrm{~h}$. Then, $20 \mu \mathrm{M}$ ABA or $5 \mu \mathrm{M}$ flg 22 was added to the medium and peels were incubated for another $1.5 \mathrm{~h}$. In experiments with bacterial strains, the concentration used was $5.10^{8} \mathrm{CFU} \mathrm{ml}^{-1}$. Bacterial cultures were washed and resuspended in buffer 10:10. Stomatal measurements were performed after $1 \mathrm{~h}$ of incubation with the bacterial suspension. Different SV-Xan were used at a concentration of $200 \mu \mathrm{g} \mathrm{ml}^{-1}$ and were added simultaneously in incubations with Xc1231 and $1 \mathrm{~h}$ prior to flg 22 treatment. The

Table 4. Bacterial strains and plasmids used in this study

\begin{tabular}{|c|c|c|}
\hline Strains/plasmids & Characteristics & Reference \\
\hline Escherichia coli $\mathrm{S} 17-1$ & E. coli 294 thi RP4-2-Tc::Mu-Km::Tn7 integrated into chromosome & Simon et al. 1983 \\
\hline $\mathrm{XcFC} 2$ & Rif $^{\mathrm{r}}$ derived from wild-type NRRL B-1459 ${ }^{\mathrm{a}}$ & Katzen et al. 1998 \\
\hline Xc1231 & NRRL B-1459 Tc::Tn10 $\Delta$ gum & Capage et al. 1987 \\
\hline $\mathrm{XcF}$ & XcFC2 $\Phi(\text { gumF-lacZ-aacCl) insertion site: EcoRI (nucleotide } 7247)^{\mathrm{b}}$ & Katzen et al. 1996 \\
\hline $\mathrm{XcG}$ & $\mathrm{XcFC} 2 \Phi(\text { gum G-lacZ-aacC1) insertion site: BamHI (nucleotide } 7963)^{\mathrm{b}}$ & Katzen et al. 1996 \\
\hline $\mathrm{XcL}$ & XcFC2 $\Phi(\text { gumL-lacZ-aacC1) insertion site: PstI (nucleotide } 13708)^{\mathrm{b}}$ & Katzen et al. 1996 \\
\hline XcI & XcFC2 $\Phi\left(\right.$ gumI-lacZ-aacC1) insertion site: StuI (nucleotide 10097) ${ }^{\mathrm{b}}$ & Katzen et al. 1996 \\
\hline $\mathrm{XcFC} 2 \mathrm{pBBR} 2-\mathrm{GFP}$ & $\mathrm{XcFC} 2$ carrying $\mathrm{pBBR} 2-\mathrm{GFP}$ & This work \\
\hline Xc1231 pBBR2-GFP & Xc1231 carrying pBBR2-GFP & This work \\
\hline $\mathrm{XcF}$ pBBR2-GFP & $\mathrm{XcF}$ carrying pBBR2-GFP & This work \\
\hline XcG pBBR2-GFP & XcG carrying pBBR2-GFP & This work \\
\hline XcL pBBR2-GFP & XcL carrying pBBR2-GFP & This work \\
\hline XcI pBBR2-GFP & XcI carrying pBBR2-GFP & This work \\
\hline $\mathrm{XcFC} 2$ pBBR2 & $\mathrm{XcFC} 2$ carrying pBBR2 & This work \\
\hline Xc1231 pBBR2 & Xc1231 carrying pBBR2 & This work \\
\hline $\mathrm{XcF}$ pBBR2 & $\mathrm{XcF}$ carrying pBBR2 & This work \\
\hline XcG pBBR2 & XcG carrying pBBR2 & This work \\
\hline XcL pBBR2 & $\mathrm{XcL}$ carrying pBBR2 & This work \\
\hline XcI pBBR2 & XcI carrying pBBR2 & This work \\
\hline \multicolumn{3}{|l|}{ Plasmids } \\
\hline pBBR2 & pBBR1-MCS derivative, mob-site, $\mathrm{LacZ} \alpha+, \mathrm{Kn}^{\mathrm{r}}$ & $\begin{array}{l}\text { Kovach et al. } 1994 \\
\text { Kovach et al. } 1995\end{array}$ \\
\hline pBBR2-GFP & pBBR2 carrying the $g f p$ gene & Posadas et al. 2012 \\
\hline
\end{tabular}


aperture of 40 stomata was measured for each treatment at $400 \times$. Data are presented as the average from 80 or 120 aperture measurements, collected from two or three independent experiments.

\section{ACKNOWLEDGMENTS}

We thank R. Vena from IBR for assistance with the CLSM. M. I. Bianco, P. M. Yaryura, N. Mielnichuk, G. E. Gudesblat, M. R. Marano, L. Ielpi, and A. A. Vojnov are Career Investigators of CONICET, L Toum and $\mathrm{R}$ Roeschlin were supported by a doctoral and postdoctoral scholarship from CONICET. This work was supported by Proyectos de Investigación Plurianuales (PIP) CONICET 2012-2014 00677 and PICT 2013-2016 1045.

\section{LITERATURE CITED}

Adam, L. and Somerville, S. C. 1996. Genetic characterization of five powdery mildew disease resistance loci in Arabidopsis thaliana. Plant J. 9:341-356.

Aslam, S. N., Newman, M. A., Erbs, G., Morrissey, K. L., Chinchilla, D., Boller, T., Jensen, T. T., De Castro, C., Ierano, T., Molinaro, A., Jackson, R. W., Knight, M. R. and Cooper, R. M. 2008. Bacterial polysaccharides suppress induced innate immunity by calcium chelation. Current Biol. 18:1078-1083.

Bergmann, D., Furth, G., and Mayer, C. 2008. Binding of bivalent cations by xanthan in aqueous solution. Int. J. Biol. Macromol. 43:245-251.

Bestwick, C. S., Bennett, M. H., and Mansfield, J. W. 1995. Hrp mutant of Pseudomonas syringae pv. phaseolicola induces cell wall alterations but not membrane damage leading to the hypersensitive reaction in lettuce. Plant Physiol. 108:503-516.

Betlach, M.R., Capage, M.A., Doherty, D.H., Hassler, R.A., Henderson, N.M., Vanderslice, R.W. and Ward, M.B. 1987. Genetically engineered polymers: Manipulation of xanthan biosynthesis. Progr. Biotechnol. 3: 35-50.

Büttner, D., and Bonas, U. 2010. Regulation and secretion of Xanthomonas virulence factors. FEMS Microbiol. Rev. 34:107-133.

Cadmus, M. C., Rogovin, S. P., Burton, K. A., Pittsley, J. E., Knutson, C. A., and Jeanes, A. 1976. Colonial variation in Xanthomonas campestris NRRL B-1459 and characterization of the polysaccharide from a variant strain. Can. J. Microbiol. 22:942-948.

Capage, M. R., Doherty, D. H., Betlach, M. R., and Vanderslice, R. W. October 1987. Recombinant-DNA mediated production of xanthan gum. International patent WO87/05938

Chan, J. W., and Goodwin, P. H. 1999. The molecular genetics of virulence of Xanthomonas campestris. Biotechnol. Adv. 17:489-508.

Denny, T. P. 1995. Involvement of bacterial polysaccharides in plant pathogenesis. Annu. Rev. Phytopathol. 33:173-197.

Dentini, M., Crescenzi, V., and Blasi, D. 1984. Conformational properties of xanthan derivatives in dilute aqueous solution. Int. J. Biol. Macromol. 6:93-98.

Donlan, R. M. 2002. Biofilms: Microbial life on surfaces. Emerg. Infect. Dis. 8:881-890.

Dow, J. M., and Daniels, M. J. 1994. Pathogenicity determinants and global regulation of pathogenicity of Xanthomonas campestris pv. campestris. Curr. Top. Microbiol. Immunol. 192:29-41.

Dow, J. M., Crossman, L., Findlay, K., He, Y. Q., Feng, J. X., and Tang, J. L. 2003. Biofilm dispersal in Xanthomonas campestris is controlled by cellcell signaling and is required for full virulence to plants. Proc. Natl. Acad. Sci. U.S.A. 100:10995-11000.

Enrique, R., Siciliano, F., Favaro, M. A., Gerhardt, N., Roeschlin, R., Rigano, L., Sendin, L., Castagnaro, A., Vojnov, A., and Marano, M. R. 2011. Novel demonstration of RNAi in citrus reveals importance of citrus callose synthase in defence against Xanthomonas citri subsp. citri. Plant Biotechnol. J. 9:394-407.

Flemming, H. C., and Wingender, J. 2010. The biofilm matrix. Nat. Rev. Microbiol. 8:623-633.

Franklin, M. J., and Ohman, D. E. 1993. Identification of $\operatorname{algF}$ in the alginate biosynthetic gene cluster of Pseudomonas aeruginosa which is required for alginate acetylation. J. Bacteriol. 175:5057-5065.

Galvan, E. M., Ielmini, M. V., Patel, Y. N., Bianco, M. I., Franceschini, E. A., Schneider, J. C., and Ielpi, L. 2013. Xanthan chain length is modulated by increasing the availability of the polysaccharide copolymerase protein GumC and the outer membrane polysaccharide export protein GumB. Glycobiology 23:259-272.

Gudesblat, G. E., Torres, P. S., and Vojnov, A. A. 2009. Xanthomonas campestris overcomes Arabidopsis stomatal innate immunity through a
DSF cell-to-cell signal-regulated virulence factor. Plant Physiol. 149: 1017-1027.

Hann, D.R. and Rathjen, J.P. 2007. Early events in the pathogenicity of Pseudomonas syringae on Nicotiana benthamiana. Plant J. 49:607-618.

Heydorn, A., Nielsen, A. T., Hentzer, M., Sternberg, C., Givskov, M. Ersboll, B. K., and Molin, S. 2000. Quantification of biofilm structures by the novel computer program COMSTAT. Microbiology 146:23952407.

Ielpi, L., Couso, R. O., and Dankert, M. A. 1981. Pyruvic acid acetal residues are transferred from phosphoenolpyruvate to the pentasaccharideP-P-lipid. Biochem. Biophys. Res. Commun. 102:1400-1408.

Ielpi, L., Couso, R. O., and Dankert, M. A. 1993. Sequential assembly and polymerization of the polyprenol-linked pentasaccharide repeating unit of the xanthan polysaccharide in Xanthomonas campestris. J. Bacteriol 175:2490-2500.

Jansson, P. E., Kenne, L., and Lindberg, B. 1975. Structure of extracellular polysaccharide from Xanthomonas campestris. Carbohydr. Res. 45: 275-282.

Joshi-Saha, A., Valon, C., and Leung, J. 2011. A brand new START: Abscisic acid perception and transduction in the guard cell. Sci. Signal 4:re4

Katzen, F., Becker, A., Zorreguieta, A., Pühler, A., and Ielpi, L. 1996. Promoter analysis of the Xanthomonas campestris pv. campestris gum operon directing biosynthesis of the xanthan polysaccharide. J. Bacteriol. 178:4313-4318.

Katzen, F., Ferreiro, D. U., Oddo, C. G., Ielmini, M. V., Becker, A., Puhler, A., and Ielpi, L. 1998. Xanthomonas campestris pv. campestris gum mutants: Effects on xanthan biosynthesis and plant virulence. J. Bacteriol 180:1607-1617.

Kim, T. H., Bohmer, M., Hu, H., Nishimura, N., and Schroeder, J. I. 2010. Guard cell signal transduction network: Advances in understanding abscisic acid, $\mathrm{CO}_{2}$, and $\mathrm{Ca}^{2+}$ signaling. Annu. Rev. Plant Biol. 61: 561-591.

Kollist, H., Nuhkat, M., and Roelfsema, M. R. 2014. Closing gaps: Linking elements that control stomatal movement. New Phytol. 203:44-62.

Koplin, R., Arnold, W., Hotte, B., Simon, R., Wang, G., and Puhler, A. 1992. Genetics of xanthan production in Xanthomonas campestris: The $x a n \mathrm{~A}$ and $x a n \mathrm{~B}$ genes are involved in UDP-glucose and GDP-mannose biosynthesis. J. Bacteriol. 174:191-199.

Kovach, M. E., Phillips, R. W., Elzer, P. H., Roop, R. M., and Peterson, K. M. 1994. pBBR1MCS: A broad-host-range cloning vector. Biotechniques 16:800-802

Kovach, M. E., Elzer, P. H., Hill, D. S., Robertson, G. T., Farris, M. A., Roop, R. M., and Peterson, K. M. 1995. Four new derivatives of the broadhost-range cloning vector pBBR1MCS, carrying different antibioticresistance cassettes. Gene 166:175-176.

Malamud, F., Torres, P. S., Roeschlin, R., Rigano, L. A., Enrique, R., Bonomi, H. R., Castagnaro, A. P., Marano, M. R., and Vojnov, A. A 2011. The Xanthomonas axonopodis pv. citri flagellum is required for mature biofilm and canker development. Microbiology 157:819-829.

Melotto, M., Underwood, W., Koczan, J., Nomura, K., and He, S. Y. 2006. Plant stomata function in innate immunity against bacterial invasion. Cell 126:969-980.

Millet, Y. A., Danna, C. H., Clay, N. K., Songnuan, W., Simon, M. D., Werck-Reichhart, D., and Ausubel, F. M. 2010. Innate immune responses activated in Arabidopsis roots by microbe-associated molecular patterns. Plant Cell 22:973-990.

Møller, S., Sternberg, C., Andersen, J. B., Christensen, B. B., Ramos, J. L., Givskov, M., and Molin, S. 1998. In situ gene expression in mixedculture biofilms: Evidence of metabolic interactions between community members. Appl. Environ. Microbiol. 64:721-732.

Murashige, T., and Skoog, F. 1962. A revised medium for rapid growth and bio assays with tobacco tissue cultures. Physiol. Plant. 15:473-497.

Murga, R., Stewart, P. S., and Daly, D. 1995. Quantitative analysis of biofilm thickness variability. Biotechnol. Bioeng. 45:503-510.

Newman, M. A., Conrads-Strauch, J., Scofield, G., Daniels, M. J., and Dow, J. M. 1994. Defense-related gene induction in Brassica campestris in response to defined mutants of Xanthomonas campestris with altered pathogenicity. Mol. Plant-Microbe Interact. 7:553-563.

O'Toole, G. A., and Kolter, R. 1998. Flagellar and twitching motility are necessary for Pseudomonas aeruginosa biofilm development. Mol Microbiol. 30:295-304.

Posadas, D. M., Ruiz-Ranwez, V., Bonomi, H. R., Martin, F. A., and Zorreguieta, A. 2012. BmaC, a novel autotransporter of Brucella suis, is involved in bacterial adhesion to host cells. Cell. Microbiol. 14:965-982.

Rigano, L. A., Siciliano, F., Enrique, R., Sendin, L., Filippone, P., Torres, P. S., Questa, J., Dow, J. M., Castagnaro, A. P., Vojnov, A. A., and Marano, M. R. 2007a. Biofilm formation, epiphytic fitness, and canker 
development in Xanthomonas axonopodis pv. citri. Mol. Plant-Microbe Interact. 20:1222-1230.

Rigano, L. A., Payette, C., Brouillard, G., Marano, M. R., Abramowicz, L., Torres, P. S., Yun, M., Castagnaro, A. P., Oirdi, M. E., Dufour, V., Malamud, F., Dow, J. M., Bouarab, K., and Vojnov, A. A. 2007b. Bacterial cyclic $\beta-(1,2)$-glucan acts in systemic suppression of plant immune responses. Plant Cell 19:2077-2089.

Romaní, A. M., Fund, K., Artigas, J., Schwartz, T., Sabater, S., and Obst, U. 2008. Relevance of polymeric matrix enzymes during biofilm formation. Microb. Ecol. 56:427-436.

Sambrook, J., and Russell, D. W. 2001. Molecular Cloning: A Laboratory Manual. Cold Spring Harbor Laboratory, New York.

Sawinski, K., Mersmann, S., Robatzek, S., and Bohmer, M. 2013. Guarding the green: Pathways to stomatal immunity. Mol. Plant-Microbe Interact. 26:626-632.

Shatwell, K. P., Sutherland, I. W., and Ross-Murphy, S. B. 1990. Influence of acetyl and pyruvate substituents on the solution properties of xanthan polysaccharide. Int. J. Biol. Macromol. 12:71-78.

Sherwood, M. T. 1970. Improved synthetic medium for the growth of Rhizobium. J. Appl. Bacteriol. 33:708-713.

Simon, R. 1984. High frequency mobilization of gram-negative bacterial replicons by the in vitro constructed Tn5-Mob transposon. Mol. Gen. Genet. 196:413-420.

Simon, R., Priefer, U., and Pühler, A. 1983. A broad host range mobilization system for in vivo genetic engineering: Transposon mutagenesis in gram negative bacteria. Bio-Technol. 1:784-791.

Sirichandra, C., Wasilewska, A., Vlad, F., Valon, C., and Leung, J. 2009. The guard cell as a single-cell model towards understanding drought tolerance and abscisic acid action. J. Exp. Bot. 60:1439-1463.

Stankowski, J. D., Mueller, B. E., and Zeller, S. G. 1993. Location of a second $O$-acetyl group in xanthan gum by the reductive-cleavage method. Carbohydr. Res. 241:321-326.

Stoodley, P., Cargo, R., Rupp, C. J., Wilson, S., and Klapper, I. 2002. Biofilm material properties as related to shear-induced deformation and detachment phenomena. J. Ind. Microbiol. Biotechnol. 29:361-367.

Tako, M., and Nakamura, S. 1987. Rheological properties of Ca salt of xanthan in aqueous media. Agric. Biol. Chem. 51:2919-2923.

Tielen, P., Strathmann, M., Jaeger, K. E., Flemming, H. C., and Wingender, J. 2005. Alginate acetylation influences initial surface colonization by mucoid Pseudomonas aeruginosa. Microbiol. Res. 160:165-176.

Torres, P. S., Malamud, F., Rigano, L. A., Russo, D. M., Marano, M. R., Castagnaro, A. P., Zorreguieta, A., Bouarab, K., Dow, J. M., and Vojnov, A. A. 2007. Controlled synthesis of the DSF cell-cell signal is required for biofilm formation and virulence in Xanthomonas campestris. Environ. Microbiol. 9:2101-2109.
Ullrich, M. 2009. Bacterial Polysaccharides: Current Innovations and Future Trends. Horizon Scientific Press, Poole, U.K.

van Hullebusch, E. D., Zandvoort, M. H., and Lens, P. N. 2003. Metal immobilisation by biofilms: Mechanisms and analytical tools. Environ. Sci. Biotechnol. 2:9-33.

Villain-Simonnet, A., Milas, M., and Rinaudo, M. 2000. A new bacterial polysaccharide (YAS34). I. Characterization of the conformations and conformational transition. Int. J. Biol. Macromol. 27:65-75.

Vojnov, A. A., and Marano, M. R. 2015. Biofilm formation and virulence in bacterial plant pathogens. Pages 1-492 in: Virulence Mechanisms of Plant Pathogenic Bacteria. The American Phytopathological Society, St. Paul, MN, U.S.A.

Vojnov, A. A., Zorreguieta, A., Dow, J. M., Daniels, M. J., and Dankert, M. A. 1998. Evidence for a role for the gumB and gumC gene products in the formation of xanthan from its pentasaccharide repeating unit by Xanthomonas campestris. Microbiology 144:1487-1493.

Vojnov, A. A., Slater, H., Daniels, M. J., and Dow, J. M. 2001. Expression of the gum operon directing xanthan biosynthesis in Xanthomonas campestris and its regulation in planta. Mol. Plant-Microbe interact. 14: 768-774.

Vojnov, A. A., Bassi, D. E., Daniels, M. J., and Dankert, M. A. 2002. Biosynthesis of a substituted cellulose from a mutant strain of Xanthomonas campestris. Carbohydr. Res. 337:315-326.

Vu, B., Chen, M., Crawford, R. J., and Ivanova, E. P. 2009. Bacterial extracellular polysaccharides involved in biofilm formation. Molecules 14:2535-2554.

Webb, A. A., McAinsh, M. R., Mansfield, T. A., and Hetherington, A. M. 1996. Carbon dioxide induces increases in guard cell cytosolic free calcium. Plant J. 9:297-304.

Xiao, J., Klein, M. I., Falsetta, M. L., Lu, B., Delahunty, C. M., Yates, J. R., 3rd, Heydorn, A., and Koo, H. 2012. The exopolysaccharide matrix modulates the interaction between $3 \mathrm{D}$ architecture and virulence of a mixed-species oral biofilm. PLoS Pathog. 8:e1002623.

Yun, M. H., Torres, P. S., El Oirdi, M., Rigano, L. A., Gonzalez-Lamothe, R., Marano, M. R., Castagnaro, A. P., Dankert, M. A., Bouarab, K., and Vojnov, A. A. 2006. Xanthan induces plant susceptibility by suppressing callose deposition. Plant Physiol. 141:178-187.

Zeng, W., and He, S. Y. 2010. A prominent role of the flagellin receptor FLAGELLIN-SENSING2 in mediating stomatal response to Pseudomonas syringae pv tomato DC3000 in Arabidopsis. Plant Physiol. 153: 1188-1198.

Zipfel, C., Robatzek, S., Navarro, L., Oakeley, E. J., Jones, J. D., Felix, G., and Boller, T. 2004. Bacterial disease resistance in Ara bidopsis through flagellin perception. Nature 428:764-767. 